\title{
Hypoadiponectinemia Is Closely Associated with Impaired Nitric Oxide Synthase Activity in Skeletal Muscle of Type 2 Diabetic Subjects
}

\author{
Sangeeta R. Kashyap, M.D.,' Linda J. Roman, Ph.D., ${ }^{1}$ Lawrence Mandarino, Ph.D., ${ }^{2}$ \\ Ralph DeFronzo, M.D., ${ }^{2}$ and Mandeep Bajaj, M.D. ${ }^{3}$
}

\begin{abstract}
Objective: In vitro studies suggest that adiponectin plays an important role in nitric oxide (NO) generation. We studied the relationship between plasma adiponectin and skeletal muscle nitric oxide synthase (NOS) activity in type 2 diabetic (T2DM) patients.

Methods: We determined NOS activity in skeletal muscle of 7 T2DM and 8 nondiabetic control subjects under basal conditions and after a 4-h euglycemic insulin $\left(80 \mathrm{mU} / \mathrm{m}^{2} \cdot \mathrm{min}\right)$ clamp.

Results: Insulin-stimulated glucose disposal (Rd) $(5.2 \pm 0.4$ vs. $9.0 \pm 0.9 \mathrm{mg} / \mathrm{kg}-\mathrm{min}, P<0.01)$ and basal NOS activity $(107 \pm 45$ vs. $459 \pm 100 \mathrm{pmol} / \mathrm{min}-\mathrm{mg}$ protein, $P<0.05)$ were reduced in T2DM versus controls. In response to hyperinsulinemia, NOS activity increased approximately two-fold in controls $(757 \pm 244, P<0.05$ vs basal) but failed to increase in T2DM $(105 \pm 38, P<0.01$ vs. T2DM). Basal NOS protein content was similar in controls and T2DM and did not change following insulin. Plasma adiponectin was decreased in T2DM ( $4.5 \pm 0.8$ vs. $7.0 \pm 1.0 \mu \mathrm{g} / \mathrm{mL}, P<0.02)$ and correlated with insulin-stimulated NOS activity $(r=0.49, P<0.05)$ and with $\mathrm{Rd}(r=0.50, P<0.05)$. In controls and T2DM collectively, Rd correlated with insulin-stimulated NOS activity $(r=0.48, P<0.05)$.

Conclusion: Decreased plasma adiponectin correlates with impaired insulin-stimulated NOS activity and severity of insulin resistance in T2DM. Because impaired NO generation plays a central role in endothelial dysfunction and development of atherosclerosis, our results may provide a link between reduced plasma adiponectin levels and accelerated atherosclerosis in T2DM.
\end{abstract}

\section{Introduction}

$\mathrm{T}$ YPE 2 DIABETES (T2DM) is an insulin-resistant state characterized by decreased plasma adiponectin concentration and accelerated atherosclerosis. ${ }^{1}$ Plasma adiponectin levels are reduced in obese rodents and humans ${ }^{2,3}$ and in humans with T2DM. Adiponectin has been shown to have antiatherogenic and antiinflammatory effects in rodents, ${ }^{4}$ and decreased plasma adiponectin concentrations have been observed in patients with coronary artery disease. ${ }^{5}$ Adiponectin inhibits tumor necrosis factor- $\alpha$ (TNF- $\alpha$ )-induced activation of nuclear factor- $\kappa \mathrm{B}(\mathrm{NF}-\kappa \mathrm{B})$-dependent proinflammatory pathways, expression of endothelial adhesion molecules, macrophage-to-foam cell transformation, and smooth muscle cell proliferation. ${ }^{6-9}$ In human aortic endo- thelial cells, adiponectin inhibits TNF- $\alpha$-induced monocyte adhesion and suppresses gene expression of vascular cell adhesion molecule-1 (VCAM-1). ${ }^{7}$ In humans, hypoadiponectinemia is associated with insulin resistance and multiple components of the metabolic syndrome.

Atherosclerosis represents a chronic inflammatory process that is initiated by damage to the endothelium. ${ }^{10} \mathrm{~A}$ central feature of endothelial dysfunction is impaired generation of nitric oxide $(\mathrm{NO}){ }^{11}$ which exerts potent cardioprotective, antithrombotic, and antiinflammatory effects. ${ }^{12} \mathrm{NO}$ is synthesized by a family of enzymes called nitric oxide synthases (NOSs) ${ }^{12}$ which also have been shown to play an important role in maintaining normal sensitivity to insulin. ${ }^{13,14} \mathrm{~T} 2 \mathrm{DM}$ is characterized, not only by insulin resistance, but also by impaired action of insulin to stimulate NO generation in the

\footnotetext{
${ }^{1}$ Cleveland Clinic, Division of Endocrinology, Diabetes, \& Metabolism, Cleveland, Ohio.

${ }^{2}$ Diabetes Division, Department of Medicine, University of Texas Health Science Center, San Antonio, Texas.

${ }^{3}$ Diabetes and Endocrinology Division, Baylor College of Medicine, Houston, Texas.
} 
endothelium $^{15}$ and skeletal muscle. ${ }^{16,17}$ Reduced NO generation has been proposed to represent the earliest and most important defect responsible for the development of accelerated atherosclerosis in T2DM. ${ }^{10,11}$ In vitro and in vivo studies suggest that the antiatherogenic and vasoprotective properties of adiponectin are similar to those of NO. ${ }^{8-10}$ Adiponectin also stimulates NO production by increasing endothelial (e) NOS gene expression enzyme activity in bovine aortic endothelial cells, and no previous study has examined the relationship between plasma adiponectin levels and NOS activity in humans in vivo. ${ }^{18,19}$ A role for adiponectin in the regulation of $\mathrm{NO}$ generation in humans has yet to be established. In the present study, we examined the relationship between plasma adiponectin concentration and skeletal muscle NOS activity and peripheral tissue insulin sensitivity in T2DM patients.

\section{Methods}

\section{Subjects}

The study population consisted of 7 T2DM [age $=51 \pm 4$ years, $\mathrm{BMI}=31.3 \pm 1.0$, glycosylated hemoglobin $(\mathrm{HbA} 1 \mathrm{c})$ $6.8 \pm 0.9 \%$, fasting plasma glucose $[\mathrm{FPG}]=135 \pm 14 \mathrm{mg} / \mathrm{dL}]$ and 8 healthy $($ age $=45 \pm 4, \mathrm{BMI}=29.5 \pm 0.9, \mathrm{HbA} 1 \mathrm{c}=4.9$ $0.2 \%, F P G=92 \pm 2$ ) age, gender, and weight-matched nondiabetic subjects who participated in a previous report, ${ }^{17}$ and in whom stored plasma samples were available for adiponectin determination. Normal glucose tolerance was confirmed in all control subjects by 75-g oral glucose tolerance test (OGTT). Diabetic patients were treated with diet $(n=5)$ or sulfonylureas $(n=2)$. T2DM patients who had received treatment with metformin, thiazolidinedione, or insulin were excluded from the study. Mean diabetes duration was $<2$ years. Four diabetic subjects had normal fasting glucose and were diagnosed with OGTT. Oral agents were discontinued $24 \mathrm{~h}$ before the study. Other than diabetes, none of the subjects had any medical problems and none were taking any medications (other than sulfonylureas in 2 diabetics) known to affect glucose metabolism. The purpose, nature, and potential risks of the study were explained to all subjects, and written voluntary consent was obtained before their participation. The protocol was approved by the Institutional Review Board of the University of Texas Health Science Center at San Antonio.

\section{Study design}

All studies were conducted in the General Clinical Research Center of UTHSCSA at 7:00 a.m. after 12-h overnight fast. Prior to euglycemic insulin clamp, an antecubital vein was cannulated for infusion of all test substances. A second catheter was inserted retrogradely into a vein on the dorsum of the hand which was placed in a heated box $\left(60^{\circ} \mathrm{C}\right)$ to obtain arterialized blood samples. A prime $(25 \times \mathrm{FPG} / 90 \mu \mathrm{Ci})$ continuous infusion $(0.25 \mu \mathrm{Ci} / \mathrm{min})$ of $3-\left[{ }^{3} \mathrm{H}\right]$ glucose was begun $2 \mathrm{~h}$ ( $3 \mathrm{~h}$ for diabetics) before the start of the insulin clamp. Sixty minutes before the insulin clamp, percutaneous biopsy of the vastus lateralis muscle was obtained for determination of NOS activity and protein content. ${ }^{17}$ Muscle biopsy specimens $(\approx 200 \mathrm{mg}$ ) were immediately blotted free of blood, frozen, and stored in liquid nitrogen until use. At the end of the tracer equilibration period, a primed continuous insulin $(80 \mathrm{mU} / \mathrm{m} 2 \cdot \mathrm{min})$ infusion was started and plasma glucose was measured every 5 min (Beckman Glucose Oxidase Analyzer, Beckman Instruments, Fullerton, CA), and a variable infusion of $20 \%$ glucose was adjusted to maintain plasma glucose concentration constant at each subject's fasting glucose level in control group. In T2DM subjects, plasma glucose was allowed to decrease to $100 \mathrm{mg} /$ $\mathrm{dL}$, at which level it was maintained. At 30 and $240 \mathrm{~min}$ after the start of insulin, repeat vastus lateralis muscle biopsies were obtained from a site $4 \mathrm{~cm}$ distal to the first.

\section{Specific methods}

Plasma glucose specific activity was determined using barium hydroxide/zinc sulfate deproteinized plasma samples. ${ }^{17}$ Plasma insulin (Diagnostic Products, Los Angeles, CA) and adiponectin (LINCO Research, St Charles, MO) were measured by radioimmunoassay. Skeletal muscle NOS activity was measured with the NOS Detect Assay kit (Stratagene, LaJolla, CA) by quantitating the conversion of $\left[{ }^{14} \mathrm{C}\right] \mathrm{L}$-arginine (Perkin Elmer Life Sciences) conversion to $\left[{ }^{14} \mathrm{C}\right] \mathrm{L}$-citrulline, according to manufacturer's instructions. Muscle tissue (20-70 mg) was resuspended in a $10 \times$ volume of ice cold homogenization buffer $(200-700 \mu \mathrm{L})$ supplied by Stratagene. Tissue was homogenized by hand using a Kontes $0.2-\mathrm{mL}$ micro-scale tissue grinder and centrifuged in a microcentrifuge at top speed for $5 \mathrm{~min}$. The supernatant was transferred to a fresh tube and kept on ice until assayed for NOS activity. The protein content of the supernatant was determined using the Micro BCA Protein Assay kit (Pierce, Rockford, IL). Production of NO was assayed using $10 \mu \mathrm{L}$ of tissue extract for $60 \mathrm{~min}$ at room temperature and was performed as per the manufacturer's instructions. NOS activity data were normalized by the absolute amount of protein present.

\section{NOS protein content}

The amount of NOS protein in tissue homogenates was determined by immunoblot analysis using an anti-nNOS polyclonal antibody raised in goat. This antibody crossreacts with all NOS isoforms and cannot be used to distinguish which isoforms are present. Immunoblotting was performed as described, ${ }^{20}$ and enzyme-linked immunodetection of goat antibody was performed using a rabbit anti-goat immunoglobulin $\mathrm{G}$ (IgG) secondary antibody conjugated with alkaline phosphatase (Zymed, San Francisco, CA). Bands were developed with nitro blue tetrazolium $(0.3 \mathrm{mg} / \mathrm{mL})$ and 5-bromo-4-chloro-3-indolyl-phosphate $(0.15 \mathrm{mg} / \mathrm{mL})$ (Bio-Rad) according to manufacturer's instructions.

\section{Calculations}

During the postabsorptive period, the rate of glucose appearance equals the rate of glucose disappearance and was calculated as the tritiated glucose infusion rate $(\mathrm{dpm} / \mathrm{min})$ divided by the plasma tritiated glucose specific activity [disintegrations per minute $(\mathrm{dpm}) / \mathrm{mg}$ ]. During the euglycemic insulin clamp, non-steady-state conditions prevail and rates of glucose appearance and disappearance were calculated with Steele's non-steady-state equation, using a glucose distribution volume of $0.65 .^{21}$ The rate of endogenous (primarily hepatic) glucose production during the insulin clamp was calculated by subtracting the exogenous glucose infusion rate from the tracer-derived rate of glucose 


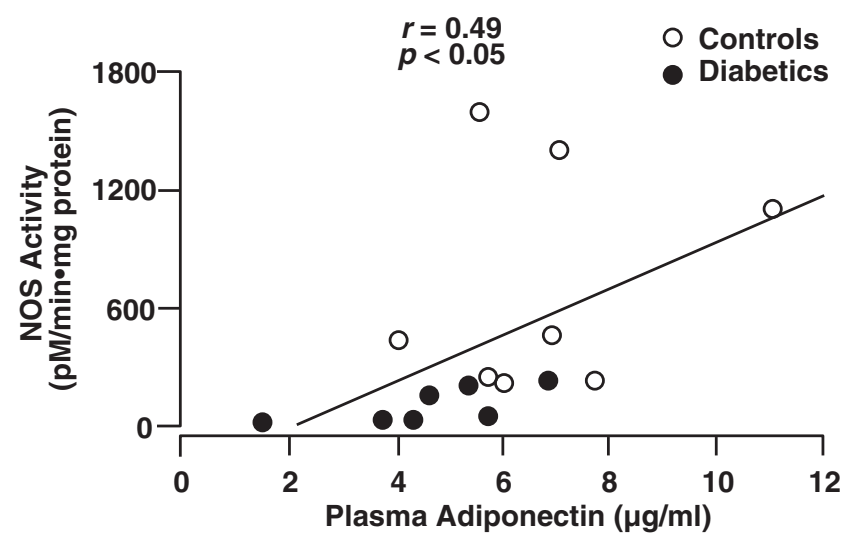

FIG. 1. Relationship between plasma adiponectin concentration and insulin-stimulated nitric oxide synthase (NOS) activity in healthy control and type 2 diabetic subjects.

appearance. The rate of insulin-stimulated glucose disposal was calculated by adding the rate of residual hepatic glucose production to the cold glucose infusion rate.

\section{Statistical methods}

All data are presented as the mean \pm standard error (SE). Differences between control and diabetic groups were compared with analysis of variance (ANOVA). Differences between basal and insulin-stimulated values within groups were compared using the paired $t$-test. Correlation analysis was performed by the Pearson product moment method using StatView software (version 4.0; SAS Inc., Cary, NC).

\section{Results}

\section{Euglycemic insulin clamp}

During the insulin clamp, similar steady-state plasma insulin concentrations were obtained in diabetic and control groups $[130 \pm 6$ vs. $126 \pm 7 \mu \mathrm{U} / \mathrm{mL}, P=$ not significant (N.S.)]. Insulin-stimulated glucose disposal (Rd) was reduced in T2DM versus controls $(5.2 \pm 0.4$ vs. $9.0 \pm 0.9 \mathrm{mg} / \mathrm{kg}-\mathrm{min}$, $P<0.01)$. Basal endogenous glucose production was increased in T2DM versus controls $(2.26 \pm 0.20$ vs. $1.90 \pm 0.09 \mathrm{mg} /$ $\mathrm{kg} \cdot \min , P<0.05)$ and insulin-mediated suppression of en- dogenous glucose production was impaired in T2DM $(0.40 \pm$ 0.07 vs. $0.07 \pm 0.02 \mathrm{mg} / \mathrm{kg} \cdot \mathrm{min}, P<0.05)$.

\section{NOS activity}

Basal NOS activity was reduced in T2DM versus controls (107 \pm 45 vs. $459 \pm 100 \mathrm{pmol} / \mathrm{min}-\mathrm{mg}$ protein, $P<0.05)$. In response to hyperinsulinemia, NOS activity increased almost two-fold in controls after $4 \mathrm{~h}(757 \pm 244 \mathrm{pmol} / \mathrm{min}-\mathrm{mg}$ protein, $P<0.05$ vs. basal) but failed to increase in T2DM (105 $\pm 38 \mathrm{pmol} / \mathrm{min}$-mg protein, $P<0.01$ controls). In control and T2DM subjects collectively, Rd correlated with insulinstimulated NOS activity $(r=0.48, P<0.05)$. Basal NOS protein content in muscle was similar in control and T2DM subjects and did not change significantly during the euglycemic insulin clamp.

\section{Plasma adiponectin}

Plasma adiponectin was decreased in T2DM subjects vs. nondiabetic controls $(4.5 \pm 0.8$ vs $7.0 \pm 1.0 \mu \mathrm{g} / \mathrm{mL}, P<0.02)$. In control and T2DM subjects collectively, plasma adiponectin correlated positively with insulin-stimulated NOS activity $(r=0.49, P<0.05)$ (Fig. 1$)$ and with $\operatorname{Rd}(r=0.50$, $p<0.05$ ) (Fig. 2).

\section{Discussion}

Adiponectin has been demonstrated to have significant antiinflammatory and antiatherogenic effects. ${ }^{6-9} \mathrm{NO}$ is a potent antiatherogenic agent, and its generation is regulated by NOS. ${ }^{11,12}$ Both endothelial dysfunction and hypoadiponectinemia are associated with insulin resistance. ${ }^{6-10,15-18}$ However, the relationship between NOS, plasma adiponectin levels, and insulin sensitivity has not been examined in vivo in humans. We report for the first time, the in vivo relationship between circulating plasma adiponectin levels, basal/insulin-stimulated NOS, and insulin-mediated glucose disposal in T2DM and age/gender/BMI-matched nondiabetic subjects. T2DM participants were severely insulin resistant and demonstrated reduced basal and insulinstimulated NOS activity. T2DM subjects also had significantly reduced plasma adiponectin concentrations that correlated with impaired insulin-stimulated NOS activity and decreased insulin-stimulated glucose disposal in skeletal
A

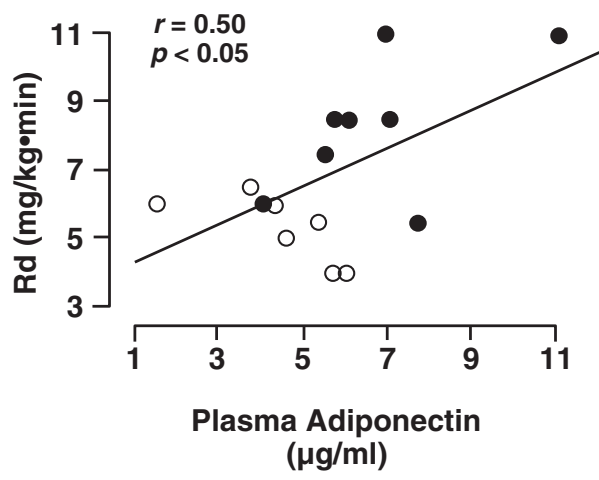

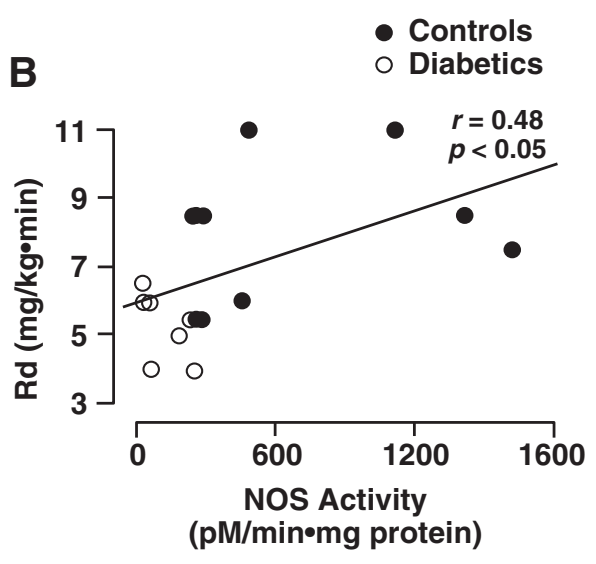

FIG. 2. Relationship between insulin-stimulated whole-body glucose disposal (Rd) and plasma adiponectin concentration (A) and nitric oxide synthase (NOS) activity (B) in healthy control and type 2 diabetic subjects. 
muscle. As previously demonstrated, ${ }^{17}$ reduced insulinstimulated glucose disposal correlated with diminished skeletal muscle NOS activity.

Diabetic subjects in the present study were characterized by short duration of diabetes ( $<2$ years) and reasonably good glycemic control (mean $\mathrm{HbA} 1 \mathrm{c}=6.8 \%$ ). However, despite good glycemic control and similar BMI, plasma adiponectin levels were significantly reduced in T2DM compared to control subjects and correlated with insulin-stimulated whole body (primarily reflects muscle) glucose disposal (Rd). These results raise the possibility that reduced plasma adiponectin concentrations represent a common mechanism that links insulin-stimulated NOS activity, endothelial dysfunction, and insulin resistance. However, given the small number of subjects who participated in the study, it may be cautioned that further studies are necessary to confirm these findings.

The relationship between insulin resistance, NOS activity, and $\mathrm{NO}$ generation in vascular tissue has been studied. . $^{15,16,22}$ Numerous studies have shown that insulin is a vasodilator and that its vasodilatory effect is mediated by NO. ${ }^{15,16}$ Moreover, insulin-resistant individuals, including diabetic, obese, and normal glucose tolerant (NGT) offspring of diabetic parents, are characterized by impaired insulinmediated vasodilation. $^{22}$ The present finding that insulinstimulated NOS activity is impaired in T2DM is consistent with these previous observations. ${ }^{15,22}$ Phosphorylation of human and bovine eNOS isoforms at serine 1,177 (or 1,179) by Akt protein kinase and adenosine monophosphate (AMP)-activated protein kinase causes a two- to four-fold increase in NO synthesis. ${ }^{23,24}$ Consistent with these observations, the insulin signaling pathway has been shown to augment NO generation in vascular endothelial cells. ${ }^{25}$ Conversely, in the aorta and mesenteric artery of insulinresistant rats, stimulation of the insulin receptor substrate-1 (IRS-1)/phosphatydilinositol-3 (PI-3) kinase pathway by insulin has been shown to be severely impaired. ${ }^{26}$ Since NOS activation by insulin in arteriolar muscle cells is dependent on an intact IRS-1/ PI-3 kinase pathway, ${ }^{25}$ insulin resistance in this pathway would be expected to impair insulinmediated vasodilation and result in endothelial dysfunction. Of note, insulin-stimulated glucose uptake in muscle and adipocytes also has been shown to be NO dependent. ${ }^{27}$ Other mechanisms that could explain reduced NO generation in T2DM include increased asymmetric dimethyl arginine (ADMA) levels and decreased cofactors required for synthesis of NO. ${ }^{28}$

In cultured bovine aortic endothelial cells, ${ }^{18,19}$ adiponectin increases NO production by stimulating eNOS expression/ activity via a PI-3 kinase-dependent pathway involving phosphorylation of eNOS at Ser1179 by AMP-activated protein kinase (AMPK). Conversly, transfection of bovine aortic endothelial cells with dominant-inhibitory mutants of AMPK inhibits NO production in response to adiponectin. Consistent with these in vitro results, impaired endotheliumdependent brachial arterial vasodilation has been associated with reduced adiponectin levels in T2DM subjects with hypertension. ${ }^{29}$

Although a correlation between reduced adiponectin levels and impaired NOS activity was observed in the present study, the cause-and-effect relationship remains unclear. With regard to this, in a rodent model chronic blockade of $\mathrm{NO}$ synthesis by $\mathrm{N}(\mathrm{G})$-nitro-L-arginine methyl ester (L-NAME) resulted in a decrease in plasma adiponectin mRNA levels in the aorta. ${ }^{30}$ Furthermore, co-treatment with pioglitazone restored plasma adiponectin concentration and fat adiponectin mRNA levels to normal. ${ }^{30}$

Several studies have shown that adiponectin stimulates muscle glucose uptake, whereas a reduction in plasma adiponectin levels is associated with insulin resistance. ${ }^{1-3}$ The present results suggest the possibility that reduced circulating adiponectin levels in T2DM may provide the link between insulin resistance, endothelial dysfunction, and accelerated atherosclerotic cardiovascular disease.

\section{Acknowledgments}

We thank all of the volunteers who participated in the study and the invaluable efforts of the GCRC nursing staff (James King, John Kincade, Norma Diaz, and Tricia Wolff) who were involved in their care. We are thankful for the skilled nursing and those who helped to perform the metabolic studies. Elva Chapa and Lorrie Albarado provided expert secretarial support in preparing the manuscript. We also thank Richard Castillo, Cindy Munoz, Sheila Taylor, and Kathy Camp for their technical support in performing the many substrate, hormone, and isotopic assays.

This work was supported by a National Institutes of Health grant NRSA (S.R.K.), National Institute of Diabetes and Digestive and Kidney Diseases (NIDDK) AM 24092, a VA Merit Award (R.A.D.), ADA Clinical Research Award (M.B.), and GCRC grant RR01346.

\section{Author Disclosure Statement}

No conflict of interest with this work.

\section{References}

1. Bajaj M, Ben-Yehuda O. A big fat wedding: Association of adiponectin with coronary vascular lesions. J Am Coll Cardiol 2006;48:1163-1165.

2. Arita Y, Kihara S, Ouchi N, Takahashi M, Maeda K, Miyagawa J, Hota K, Shimomura I, Nakamura T, Miyaoka K, Kuriyama H, Nishida M, Yamashita S, Okubo K, Matsubara K, Muraguchi M, Ohmoto Y, Funahashi Y, Matsuzawa Y Paradoxical decrease of an adipose-specific protein, adiponectin, in obesity. Biochem Biophys Res Commun 1999;257: 79-83.

3. Weyer C, Funahashi T, Tanaka S, Hotta K, Matsuzawa Y, Pratley RE, Tataranni PA 2001 Hypoadiponectinemia in obesity and type 2 diabetes: Close association with insulin resistance and hyperinsulinemia. J Clin Endocrinol Metab 2001;86:1930-1935.

4. Kubota N, Terauchi Y, Yamauchi T, Kubota T, Moroi M, Matsui J, Eto K, Yamashita T, Kamon J, Satoh H, Yano W, Froguel P, Nagai R, Kimura S, Kadowaki T, Noda T. Disruption of adiponectin causes insulin resistance and neointimal formation. J Biol Chem 2002;277:25863-25866.

5. Pischon T, Girman CJ, Hotamisligil GS, Rifai N, Hu FB, Rimm EB. Plasma adiponectin levels and risk of myocardial infarction in men. JAMA 2004;291:1730-1737.

6. Goldstein BJ, Scalia R. Adiponectin: A novel adipokine linking adipocytes and vascular function. J Clin Endocrinol Metab 2004;89:2563-2568.

7. Ouchi N, Kihara S, AritaY, Maeda K, Kuriyama H, Okamoto Y, Hotta K, Nishida M, Takahashi M, Nakamura T, Yamashita S, Funahashi T, Matsuzawa Y. Adipocyte-derived plasma protein, adiponectin, suppresses lipid accumulation 
and class A scavenger receptor expression in human monocyte-derived macrophages. Circulation 1999;100:24732476.

8. Wang Y, Lam KD, Xu JY, Lu G, Xu LY, Cooper GJ, Xu A. Adiponectin inhibits cell proliferation by interacting with several growth factors in an oligomerization-dependent manner. J Biol Chem 2005;18:18341-18347.

9. Ouchi N, Kihara S, Arita Y, Okamoto Y, Maeda K, Kuriyama H, Hotta K, Nishida M, Takahashi M, Muraguchi M, Ohmoto Y, Nakamura T, Yamashita S, Funahashi T, Matsuzawa Y. Adiponectin, an adipocyte-derived plasma protein, inhibits endothelial NF-kappaB signaling through a cAMPdependent pathway. Circulation 2000;102:1296-1301.

10. Hsueh WA, Quinones MJ, Creager MA. 1997 Endothelium in insulin resistance and diabetes. Diabetes Rev 1997;5:343-352.

11. Cannon R. 1998 Role of nitric oxide in cardiovascular disease: Focus on the endothelium. Clin Chem 1998;44:1809-1819.

12. Michel T, Feron O 1997 Nitric oxide synthases: Which, where, how and why? J Clin Invest 1997;100:2146-2152.

13. Duplain H, Burcelin R, Sartori C, Cook S, Egli M, Lepori M, Vollenweider P, Pedrazzini T, Nicod P, Thoren B, Scherrer U. Insulin resistance, hyperlipemia, and hypertension in mice lacking endothelial nitric oxide synthase. Circulation 2001; 104:342-345.

14. Shankar R, Wu Y, Shen H, Zhu J, Baron A. Mice with gene disruption of both endothelial and neuronal nitric oxide synthase exhibit insulin resistance. Diabetes 2000;49:684-687.

15. Steinberg HO, Chaker H, Learning R, Johnson A, Brechtel G, Baron AD. Obesity/insulin resistance is associated with endothelial dysfunction. J Clin Invest 1996;97:2601-2610.

16. Steinberg HO, Brechtel G, Johnson A. Fineberg N, Baron AD. Insulin-mediated skeletal muscle vasodilation is nitric oxide dependent: A novel action of insulin to increase nitric oxide release. J Clin Invest 1994;94:1172-1179.

17. Kashyap SR, Roman LJ, Lamont J, Masters BS, Bajaj M, Suraamornkul S, Belfort R, Berria R, Kellogg DL Jr, Liu Y, DeFronzo RA. Insulin resistance is associated with impaired nitric oxide synthase activity in skeletal muscle of type 2 diabetic subjects. J Clin Endocrinol Metab 2005;90:1100-1105.

18. Chen H, Montagnani M, Funahashi T, Shimomura I, Quon MJ. Adiponectin stimulates production of nitric oxide in vascular endothelial cells. J Biol Chem 2003;278:45021-45026.

19. Hattori Y, Suzuki M, Hattori S, Kasai K. Globular adiponectin upregulates nitric oxide production in vascular endothelial cells. Diabetologia 2003;46:1543-1549.

20. Towbin H, Staehelin J, Gordon J. Electrophoretic transfer of proteins from polyacrylamide gels to nitrocellulose sheets: Procedure and some applications. Proc Natl Acad Sci USA 1979;76:4350-4354.
21. Steele R, Wall J, DeBodo R, Altszuler N. Measurement of size and turnover rate of body glucose pool by the isotope dilution method. Am J Physiol 1956;187:15-24.

22. Laakso M, Edelman SV, Brechtel G, Baron AD. Decreased effect of insulin to stimulate skeletal muscle flow in obese men. J Clin Invest 1990;85:1844-1852.

23. Chen Z.-P, Mitchelhill KI, Michell BJ, Stapleton D, Rodriquez-Crespo I, Witters LA, Power DA, Ortiz de Montellano PR, Kemp BE. AMP-activated protein kinase phosphorylation of endothelial NO synthase. FEBS Lett 1999; 443:285-289.

24. Fulton D, Gratton J.-P, McCabe T.J, Fontana J, Fujio, Y, Walsh K, Franke T.F, Papapetropoulos A, Sessa WC. Regulation of endothelium-derived nitric oxide production by the protein kinase Akt. Nature 1999;399:597-601.

25. Zeng G, Nystrom FH, Ravichandran LV, Cong LN, Kirby M, Mostowski H, Quon MJ. Roles for insulin receptor, PI3kinase, and Akt in insulin-signaling pathways related to production of nitric oxide in human vascular endothelial cells. Circulation 2000;101:1539-1545.

26. Jiang Z, Lin Y-W, Clermont A, Igarashi M, King G. Direct demonstration of selective insulin resistance on PI 3 kinase pathway in vascular tissues of obese Zucker ( $\mathrm{fa} / \mathrm{fa}$ ) rats. Diabetes 1997;46:54A.

27. Roy D, Perreault M, Marette A. Insulin stimulation of glucose uptake in skeletal muscles and adipose tissues in vivo is NO dependent. Am J Physiol Endo Metab 1998;274: E692-E699.

28. Williams IL, Wheatcroft SB, Shah AM, Kearney MT. Obesity, atherosclerosis and the vascular endothelium: Mechanisms of reduced nitric oxide bioavailability in obese humans. Int $J$ Obes 2002;26:754-764.

29. Tan KC, Xu A, Chow WS, Lam MC, Ai VH, Tam SC, Lam KS. Hypoadiponectinemia is associated with impaired endothelium-dependent vasodilation. J Clin Endocrinol Metab 2004;89:765-769.

30. Hattori S, Hattori Y, Kasai K. Hypoadiponectinemia is caused by chronic blockade of nitric oxide synthesis in rats. Metabolism 2005;54:482-487.

Address correspondence to: Mandeep Bajaj, M.D. Diabetes and Endocrinology Division Department of Medicine Baylor College of Medicine 1709 Dryden Street Houston, TX 77030

E-mail: mandeepbajaj@hotmail.com 
